\title{
3 \\ Returning to country: The Docker River project
}

\author{
Jeremy Long
}

A short account of the return to the Petermann Ranges might begin with the stirring of interest in the Welfare Branch of the Northern Territory Administration in Darwin in 1958 and end with the arrival of Max Cartwright, the first manager, at the nascent Docker River outstation in late December 1967. I thought it more interesting to start the story earlier to illustrate how ideas about the use of Aboriginal reserves changed over time. In 1920, when the large South West or Lake Amadeus Reserve was created, it was intended to rule out any alienation of the land as well as allowing the inhabitants to continue in undisturbed occupation. Nevertheless, the Mackay Exploring Expedition, which included Dr Herbert Basedow, was allowed to traverse the range in the winter of 1926 and reported that the country was exceedingly dry but that the party had friendly contact with groups of up to 30 or 40 of the locals. ${ }^{1}$

In 1928, J. W. Bleakley, the Chief Protector of Aborigines in Queensland, was engaged by the Commonwealth Government to report on the 'present status and conditions of aboriginals' in the Territory. In Alice Springs, he learnt that 'two exploring missionaries' had visited the Petermann Ranges that winter and had reported seeing a large number of people in the reserve. Possibly on their advice, he recommended extending the reserve 'north and east' to embrace 
country 'containing primitive tribes', and he proposed establishing 'one or more mission stations-Lutheran suggested-to exercise supervision over the conditions and to relieve where privation is evident' (Bleakley 1929: 35). Clearly, his general aim was to preserve some of 'this fast dying race' by encouraging the inhabitants to stay away from the settled areas and even return from those areas.

No action was taken on these recommendations. At that time, and for the next three years, Central Australia was being administered separately from the northern part of the Territory and the small staff was not likely to give any priority to such a scheme. By 1931, when Central Australia was again administered from Darwin, the Chief Protector Dr Cecil Cook likewise had few resources and little chance of gaining more in those Depression years. He did not share Bleakley's enthusiasm for having missions take responsibility for the 'benevolent supervision' of the areas reserved for 'nomadic aborigines', and he regarded the congregations of people that resulted as a health hazard.

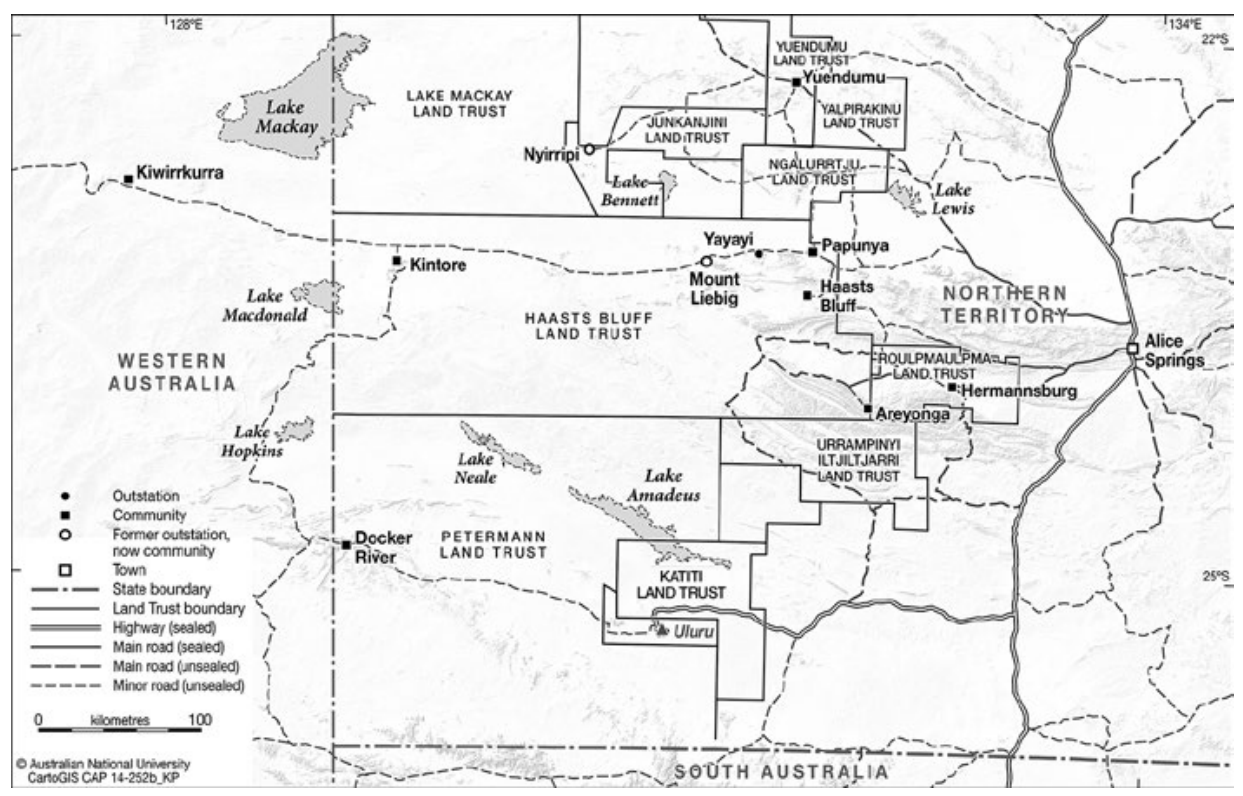

Map 3.1 Docker River in relation to Areyonga and Haasts Bluff.

Source: Karina Pelling, CartoGIS, ANU College of Asia and the Pacific

An inquiry in 1935 into alleged misconduct by police responsible for what was known as the 'South West Patrol' recommended that police patrols should be replaced with patrols by an officer directly responsible to the chief protector and that the reserve should be surveyed to see whether 'a government Aboriginal station and medical depot might usefully be established there' (Long 1992: 168). This inquiry did lead to the appointment of T. G. H. Strehlow as a patrol 
officer in Central Australia. Even before he formally took up duty, he was dispatched with camels in July 1936 to visit the Petermanns and report on stories of a violent encounter there between a prospecting party and the local men. His inquiries indicated that the story was almost certainly a concoction. He reported that game was scarce and the native population sparse; but he did propose that a ration depot be established in the reserve to relieve the situation and ensure that the reserve was not completely evacuated in the next few years.

Again, nothing followed from these proposals, but three years later Dr Cook was replaced with the director of a newly established Native Affairs Branch, E. W. P. Chinnery, who took up duty in February 1939. He was charged with responsibility for implementing a new policy with the long-term aim of raising the status of 'these native Australian people' to 'entitle them by right, and by qualification to the ordinary rights of citizenship'. The policy announced by (later Sir) John McEwen, Minister for the Interior, stated that those 'still living in tribal state' would be protected 'from the intrusion of whites'. It was envisaged that "missions or district officer stations will be maintained to act as buffers between the tribal natives and the outer civilization' (McEwen 1939: 3). 'Visiting patrols' were to keep in touch with 'even the most backward peoples' and one of the first three 'district stations' was to be 'in the south-west portion of the territory'. The plans for these stations were spelt out at some length: the aim was to prepare 'the aboriginals gradually to develop in their own way, within their own reserves, rather than drift into distant settlements seeking employment or sustenance only to become hangers on, as many of them now are' (McEwen 1939: 4).

It seems that Chinnery was not initially convinced of the need for a district station in the south-west, but conversations with Pastor Friedrich Albrecht, who was in charge at Hermannsburg, persuaded him of the urgent need to provide at least a ration depot in the Haasts Bluff area and to investigate the need for something in the Petermann Ranges. What resulted was a kind of 'joint patrol' involving Albrecht himself, a party from the Ernabella Mission and Strehlow. Early in July, Strehlow first dispatched from Hermannsburg a three-man team with 12 camels to take supplies for the party to Piltadi Rockhole in the Petermanns. ${ }^{2}$ Strehlow then set off in his truck for the recently established Ernabella Mission in South Australia, taking with him Pastor Albrecht and Oswald Heinrich, a farmer and supporter of the mission. There they were joined by the Reverend Harry Taylor, superintendent of the mission; Roy Edwards, secretary of the Aborigines Protection League in Adelaide; and Dr Charles Duguid. Duguid had been instrumental in persuading the Presbyterian Church and the State

2 Report on Trip to the Petermann Ranges, July-August 1939 (22 pp.), AA CRS A659 34/1/15262, Commonwealth Archives. 
Government in 1937 to back his plan to set up at Ernabella the sort of 'buffer' station envisaged in McEwen's policy. With the larger Ernabella truck as fully loaded as Strehlow's, the party set off on a slow and circuitous four-day drive, following existing wheel tracks, to meet the camel party at Piltadi. They then spent 10 days having a close look at the western Petermanns with the camels.

Strehlow's lengthy and detailed account of the journey and of his conclusions told much the same story as his earlier report: the area was still suffering from a run of relatively dry years, the remaining inhabitants were few - the party met just 26 men, women and children - and he thought it likely that altogether only 50 or 60 people remained: "The "leave 'em alone" policy has done its worst: a chapter in the history of the Petermann Range natives has closed for ever.' But Strehlow saw potential for raising cattle there if wells were sunk in the reserve. If a government ration depot were established, workers could supply their own meat and 'nomads' could earn cash by bringing in dingo scalps. Strehlow's main concern was with 'the hundreds of homeless Petermann natives ... wandering about' in the settled areas, the younger ones 'degenerating into a race of useless wasters'. He hoped that 'the Government will have sufficient humanity to save the aboriginal from extinction while yet there is time' ${ }^{3}$

Chinnery wrote back to Strehlow on 29 August asking for details of what was needed to establish a depot and an estimate of the costs. ${ }^{4}$ Strehlow's relatively brief response, dated 9 September 1939, suggested three likely sites to test for water and again proposed that a road should first be made between Hermannsburg and Ayers Rock (Uluru) and thence to the Petermanns. This could be done by a team of six Aboriginal labourers with a two-tonne truck, under his direction, in about 10 weeks. ${ }^{5}$

The dates of this exchange may serve to explain why no action followed. The scheme was effectively put on hold with the outbreak of war. The civil administration did not disappear in 1940, but military needs took priority. The Army offered work to a few men from Central Australia, but the main emphasis was soon on removing the aged, infirm and unemployed Aboriginal people from Alice Springs - first to Jay Creek, but there the water supply was inadequate to provide for the numbers. The Army then backed a 1940 proposal for a ration depot at Haasts Bluff, paid for by the Administration and supervised by patrol officer Strehlow, but managed by the Hermannsburg Mission. The military authorities were also keen to clear people from the sidings on the

ibid.

AA CRS: F1 38/418: memorandum, 29 August 1939.

AA CRS: F1 38/418: memorandum, 9 September 1939. 
rail line south of Alice Springs and backed the establishment in 1943 of a similar depot at Areyonga, intended to attract people who had moved east from the Petermann Ranges.

The South West Reserve remained as desolate as Strehlow had feared. In the postwar years, some of the several private expeditions to the ranges were accompanied by an officer from the Native Affairs Branch (latterly the Welfare Branch). Patrol officer John Bray reported on a January 1951 visit by a party interested in the area's mineral potential, and was impressed enough by the country to suggest that it was a suitable place for a settlement. This party met just one group of nine men, women and children (Long 1963: 8). Bray's suggestion was endorsed in 1958 when a joint examination of the South Australian, West Australian and Northern Territory reserves was made by a party including Max Althaus, superintendent at Areyonga, and Clarrie Bartlett from the SA Aboriginal Affairs Department, which was proposing a new government station west of Ernabella (Long 1992: 133). This prompted the Welfare Branch of the Administration to submit a proposal for a settlement in the South West Reserve.

In January 1959, the Department of Territories in Canberra responded, rejecting the idea on the grounds that a settlement would have 'a better chance of fulfilling its purposes ... [near] a closely settled area'. ${ }^{6}$ It was 'necessary to encourage movement to more settled areas' and if the area in the ranges was 'suitable for pastoral purposes just as much opportunity could be provided by making the land available to private enterprise'. ${ }^{7}$ Since Paul Hasluck, the Minister for Territories since 1951, took a very close interest in Territory administration, it is hard to imagine that these comments did not reflect his views. He had agreed in 1958 to the excision of the Mount Olga-Ayers Rock area from the reserve, after being assured that no Aboriginal people had been living there for many years.

Proposals had also been made at this time that a single authority might be set up to administer the adjoining 'Central Reserves' in Western Australia, South Australia and the Northern Territory, which by then were affected by the operations of the Weapons Research Establishment (WRE) based at Woomera. The area of the reserves in WA and the NT was then being greatly extended, after a 1957 patrol to the area near Lake Mackay had confirmed that there were people living outside the reserves. The South West Reserve became part of a much larger one in 1959 with the gazetting of the Lake Mackay Aboriginal Reserve and the WA reserve was extended northward to match the NT expansion. Hasluck rejected the idea of a separate authority, but accepted the need for closer cooperation. When the Commonwealth and State ministers responsible for Aboriginal affairs (the Native Welfare Conference) met in January 1961,

AA CRS: F1 59/333: minute, 28 March 1961.

ibid. 
they agreed to set up a consultative committee to exchange information and coordinate practice in the Central Reserves. The first meeting was held in Alice Springs in mid-August 1961, attended by one of the two patrol officers employed by the WRE (Long 1963: 8).

Meanwhile, in late March 1961 (about six months after I started as a research officer with the Welfare Branch), I submitted proposals for research related to the need I saw for accelerated development to meet the needs of the growing populations in the three western settlements, as the records of births and deaths at Yuendumu and Papunya had shown that populations there had been increasing since the mid-1950s. ${ }^{8}$ It seemed clear to me that the 'settled areas' in Central Australia were not able to provide work for these people and even less likely to provide for their growing populations. To hope that the settlements might in the short term 'serve their purposes as "staging camps" and "training centres" and disappear' seemed unrealistic. I noted existing plans for sinking bores north-west of Areyonga for a subsistence cattle project and suggested that bores should also be sunk in the Petermann Ranges to provide three or four watering places for a cattle project there. I also suggested that bores should be sunk west of Mount Liebig, to expand the Haasts Bluff cattle project to the Ehrenberg Range, noting that it seemed likely that it would be 'necessary and desirable to establish another Settlement at or west of the Kintore Range within the next ten years'. ${ }^{9}$

I spent a fortnight at Areyonga in August 1961 and submitted a report on 'the movements and rate of growth' of the population there, noting that the people were markedly more mobile than those in the other settlements; that the prospects for development of a cattle project there were severely limited; and that the water supply might be inadequate for a growing population. ${ }^{10}$ Developing the Petermann Ranges area offered much better prospects. It would certainly 'arouse real interest and enthusiasm in the Areyonga community'; I was told that the leader of a team making a road to a new bore site had proposed that they next make a road to the Petermanns. I suggested that an 'outpost station' (comparable with the Fregon outstation of Ernabella recently established in the north of South Australia) would be 'a start towards ensuring some future for these people', as well as reducing 'the number of families moving round the stations and sitting down on the Ayers Rock road' and would also 'provide a much needed service for the people of the Rawlinsons who tend to sit down at Giles where they are a constant problem for the Weather Station and the WRE patrol officers'. I suggested that the aim might be to keep the population in the 100 to 150 range and 'to plan for at least two small stations, one towards 
the eastern end of the ranges and the main settlement near the western end'. I hoped that a patrol officer might visit the Petermann Ranges 'to record the extent of the mulga and grass country there' and its potential for 'development based on pastoral activity'. ${ }^{11}$

This was quickly agreed to, and on 16 September, patrol officer John Hunter and I left Areyonga with two guides: a senior man from the western area and a younger man who had recently been out to the ranges with camels. In a week, we travelled the length of the ranges, including areas on the southern side of the main range. We reported meeting just one group of people, near the WA border, and finding the country very dry, but we had seen kangaroos every day. We were impressed with the potential for cattle grazing in several areas. We endorsed the view, urged by Bartlett and Althaus after the 1958 joint patrol and again by the recent Central Reserves Committee (CRC) meeting in Alice Springs, that 'the Reserves in this area should be developed to provide useful employment, a place to live and prospects of further economic advancement for their original inhabitants, as well as to reverse the drift into pauperism on the stations, in towns and on tourist routes' ${ }^{12}$ We recommended initial test boring for water near the existing well-marked track from Ayers Rock and Mount Olga:

The Kikingura/Docker River area has the most appeal as a site for the establishment of a first trading-post-cum-cattle station. This is an area with great ceremonial and emotional significance for the Areyonga people; it is handy to the Rawlinson area, Giles and the graded roads of the WRE; it is central to some useful grazing areas and is well situated for the control of entry to this section of the Reserve ... Outstations should be established early, south of the Range and towards the eastern end near the Irving Creek. ${ }^{13}$

We also indicated that a community there would provide 'a contact point convenient for the Rawlinson natives and those to the north-west' an alternative to the Giles Weather Station.

On 28 September 1961, the director of welfare in Darwin, Harry Giese, drafted a four-page memorandum for the Administrator to send to Canberra, headed 'Outstations on Settlements in Central Australia'. ${ }^{14}$ He began by mentioning discussion at the August meeting of the CRC in Alice Springs about decentralising activities on the settlements, noting that these communities had been built to accommodate at most 350 people and now had much larger populations. He reported the establishment of small 'village' groups on bores a few miles from Yuendumu and referred to 'sporadic attempts' to establish similar small

11 ibid.

12 AA CRS: F1 61/3022: minute, 29 September 1961.

13 ibid.

14 AA CRS: F1 69/1864: memorandum, 9 October 1961. See Appendix 3.1. 
groups at bores near Papunya. He mentioned proposals for more bores west of Papunya and made a recommendation that an outstation of the Haasts Bluff cattle operation was needed at the Mount Liebig end of the run. He indicated that this might be an attractive location for perhaps 100 to 150 of the Pintubi group at Papunya and listed the facilities needed at such an outstation. He also outlined plans for the development of a similar outstation from Areyonga, if boring to the north-west was successful, and possibly at least one 'small native village'. Field reports on the Petermann Ranges patrol would be examined before making any recommendation to the minister on development there. Meanwhile, he sought 'clearance in principle' of the proposal for an outstation in the Mount Liebig area.

This message was apparently sent on 9 October and the reply on 25 October reported that the minister had approved the general principle of decentralisation with 'outstations or village areas' and that proposals for the Mount Liebig outstation be developed for the 1962-63 draft estimates. Hasluck had commented that any outstation given 'substantial buildings and facilities' ought to have a prospective life of 20 to 25 years and that careful consideration should be given to the educational policy question of whether children would be better served by one larger central school than by several smaller ones. ${ }^{15}$

My report on the Petermann Ranges patrol was sent to Canberra with a recommendation to approve in principle the establishment of a community and to make provision for test drilling of bores in the area. The minister gave general approval to the suggested development in the Petermann Ranges and approved that 'provision be made in the 1962/63 programme for four bores to be sunk, one of which will be equipped in the areas suggested by Mr Long, subject to further investigation by officers of the Animal Industry Branch' (AIB). ${ }^{16}$ In July 1962, Giese asked the director of the AIB to have officers visit the area and comment on carrying capacity, location of water, fencing, annual turn-off and so on.

It was at this point that the 'green' opposition to the proposed introduction of cattle (and horses) into the area was revealed. The AIB botanist had been to the Petermanns with the 1958 party and had then expressed concern about the suggestion that a settlement should be developed there. Now he was supported by the field biologist, who let me know that their concern was that the last ungrazed mulga community in Australia is there' (personal communication). We met and agreed that an area should be set aside for scientific purposes as a flora and fauna reserve. In the event, no cattle were grazed in the Petermanns, but that is another story.

15 AA CRS: F1 69/1864: memorandum, 25 October 1961.

16 AA CRS: F1 69/1864: memorandum, 27 July 1962. 
The next April (1963), with a trainee patrol officer, I picked up two senior men from Areyonga and drove to the Petermanns to join the geologist and the boring contractor, who were selecting seven or more possible drilling sites. The Water Resources Branch provided a 'completion report' in April 1964 on a bore at the Docker River, equipped with a mill and tank, recommending that it should be equipped to pump 4,500 litres an hour. Plans for an outstation were then developed in the Alice Springs office. Initially, it would have a manager and a nursing sister, and, when enough children of school age were present, a teacher. Creed (T. C.) Lovegrove, a senior official first in the Native Affairs division of the Welfare Branch and later in the Department of Aboriginal Affairs, submitting his plans in 1965, noted:

The manager will have to be very self sufficient during the early developmental period of this outstation. He will need to have some experience with Aborigines, know something about building, and be able to repair his own vehicle and maintain the water supply if necessary. (Cartwright 1994: 78)

An airfield site was chosen. Drought-breaking rain in 1966 and heavy falls in February 1967 caused delays in taking out caravans and a demountable house. The Docker River overflowed and demonstrated that the bore was in a floodprone area. The building supervisor, who was there at the time, had everything moved to a better site away from the bore. I made a visit to the Petermanns in April 1967, on the way to a CRC meeting at Giles, and another in September 1967, joining the Australian Institute of Aboriginal Studies (AIAS) film unit and a team of 19 men from Areyonga for the filming of rituals relating to the Kikinkurra area. Coincidentally, in April, Neville Harding, one of the most determined seekers of Lasseter's fabled reef of gold, had led a party of 14 men with several four-wheel-drive vehicles and a Cessna aircraft to prospect in the western Petermanns (Cartwright 1994: 72). Harding was still out, camped south of the main range, in September.

In December two patrol officers took out a small party of Areyonga men to begin work on clearing the airstrip. A few days later, Max Cartwright, the first manager of the outpost, arrived with more men from Areyonga. Max has written an excellent account of the first year of the Docker River outpost. Through the heat of January, work on the airstrip remained the priority for him and his team of 14 men working a six-day week. On their day off, he drove them out to visit places of interest to them and to do some hunting, and as a change from the airstrip work, they also laid out some roads in the community, planted trees and made a new road crossing of the Docker River. Cartwright started a 'social club' where the men could spend some of their pay on soft drinks, biscuits, cigarettes and other extras. 
By February, he records that the population 'was starting to expand slightly, with a few people arriving by any means possible'. He made his first visit to Giles and a week later returned to pick up a family of 'bush people' who had recently reached Giles in 'destitute condition'. On one of their days off, he and the men visited 'Wanguri', where Harding had camped and found there an abandoned four-wheel-drive truck, which he promptly had 'in running order' as a useful addition to the outstation's equipment. In March, he drove to Ayers Rock to collect some 30 people trucked from Areyonga and brought them on to the outstation; and in April he collected two families who had walked as far as Giles from the Warburton Ranges Mission. In May the Areyonga truck brought another 18 people, along with a DCA roller to improve the airstrip. A journalist who visited in late May reported a population of about 80, including 25 schoolchildren, a teacher having been supplied in late February. In August several families arrived by car from Warburton.

In May the first tourist group arrived and later some VIP travellers visited (Bill and Barbara Wentworth in August; Sid and Cynthia Nolan in October). In the winter months, nursing sisters were sent out to help with influenza outbreaks. Giese and Lovegrove made a visit of inspection in August - the 'whole population were at the airstrip to witness the event' - and attended a council meeting where 'various hopes were expressed for the future'. A few petrol sniffers had made a nuisance early. Cartwright recorded the first big fight in late November. In January, he handed over to his successor as manager, John Smith.

\section{References}

Bleakley, J. W. 1929. The Aboriginals and Half-castes of Central Australia and North Australia. Commonwealth Parliamentary Paper 21. Canberra: Commonwealth of Australia.

Cartwright, M. 1994. From Bush Track to Highway. Wollongong, NSW: Leisure Coast Graphics.

Long, J. P. M. 1963. Preliminary Work in Planning Welfare Development in the Petermann Ranges. Australian Territories 3(2): 4-12.

Long, J. P. M. 1992. The Go Betweens: Patrol Officers in Aboriginal Affairs Administration in the Northern Territory 1936-1974. Darwin: North Australia Research Unit.

McEwen, J. 1939. Commonwealth Government's Policy with Respect to Aboriginals. Canberra: Commonwealth Government Printer. 


\section{Appendix 3.1}

\section{Outstations on settlements in Central Australia}

The Secretary,

Departwent of Territories, CANRARRA.

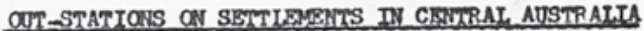

Following consideration of the question of establishing out stations on various settloments in Central hustralla as discussed at the Conference with representatives of the Western Australlan and South Australlan Governments in Alice Springs recently, the DIreotor of Welfare has been glving consideration to the whole problem of decentraliaing act1vities on these settlements.

2. You will knou that there are larpe mubers of aborlgines congregated around settlements 11ke Inenduma (total popplation 466), Papunya and Hasats Bluff (603), and Areyonga (357), and that these congregations create major probloms of water supply and gettlement hyglene and place an undue strain on communt ty facillt1es which have been bullt to accomodate at the outalde 350 persons. In Central Australla at all these settlements, water supply, because of the fact that the water cones fron underground sources, and settlement hyglene becsuse of the stage of development of personal and community hyglene of the people, present major diffeculties and this position must contime for a good many years to como.

3. The process of decentralisation has alroady been started in a small way with solocted Pamilies at Juenduma where fanily groups are nov resident at Penhall's and Wh1te Polnt Bores. These bores are situated approxinately four and nine wiles fros the Settlement 1tself. These distances are such that chlldren can walk to school from Penhall's and can be transported from White Point Bore, and the lhuraing Sister fron tho Settlement can make regular visits to the areas to care in particular for the mothers, bables and pre-school children. At the present timo, dovelopment at these two places consists of a gmall market garden, a smail oitrus grove, and the beginnings of a Incerne area. At both also, some attempt Is being wade to erect a small native village using local naterials of stone and I1me. During portion of the year when water is in the eroek, the Kerridy area is also used for a similar purpose and plans are belng developed to increase the capacity to enable water to be beld here for the whole year. As further waters are provlded by dams or bores in th Reserve, it is proposed to extend these amall out-stations and to deve. sone citrus orchards, merket gardens and lucermplots as well.

This dovelopment has been proceeding quietly at Yuendumu and has enabled the water supply which is in short supply at the settlement area, to be sufficient for 1 mmediate settlement requlrements. Because of the difficulties of getting underground water, it is planned to establish a large dan at the Settlernent and under these circumstances there showld bo sufficient water to maintain essential Settlemont services and a nativo village but without any lergo agricultural or orchard development in this area. It must be cuite obvious that under these elroumatances whare the water supply, whether by bore or surface wator, will always present difficultios, and where the standards of personal and communty hyglene are poor, sowe such decentralisation as is at present belng practised at Yuendumu, is inevitable.

4. The situation in the Papunya area is bolng exacerbated by thr movement of prinitivo natives from the western areas in falrly large mumbers and in view of this, sowe decentralisation of activities in

$$
\begin{aligned}
& \text { USTRALIANARCHIVES, WU GEGION } \\
& \text { CA ?70 ADMINTISTRATOR, N.T (III) } \\
& \text { CRSFI ITEM: } 69 / 1864 \ldots / 2
\end{aligned}
$$

A handwritten date of $9 / 10 / 61$ has been omitted from the top of the scan of the document in order to fit the scan on this page. 
this area also appears 1nevitable. Sporadio attenpts have been made to establish small proups at Ekraoorra and Allumbra bores but in the absence of staff and vehicles to supervise and service these aress, the projects have not been naintained. At the present time the water supply at Papunya 1s adequate for present settlement needs and to enable the malntenance of a small market garden and oftrus orchard in addition to a small lucerne plot. Howover, with the extension of the native village with more people reaching a stage where thoy can bo accormodated in small houses and not wurlles, there will bo Increased demend for water on this settlement. There is still a bore in reserve which will be equipped this year and which will provide some reserve for the future; however, 1t seems clear that if possible the numbers on this settlement should not exceed 350 when the people are housed in a reasonable village area. At the present time there are bores at Ekracowra ( 3 miles east of Papunya), Allutbra (15 miles west), Lolbig ( 30 miles west) and a further bore ten miles west of Lelbig which has just been equipped. All these bores are on the north of the Haasts Bluff Range and would offer sone possibllities for decentralisation activities. In addition, a further bore $1 \mathrm{~s}$ being sunk $15 \mathrm{mlles}$ southwest of the bore west of $\mathrm{Mt}$. Lolblg and another bore will be sunk south agaln of this to the west of the Marint Rance. The bores west of Mt. Ielb1g are on the edge of some good eattle country which, with the waters, will now be opened up, end as well extends Into the tribel country of the PIntubl eroup.

At the present time this country is being supervised and managed from the Hasts Bluff homestead whlch, as you will appreclate, Involves staff In moving considerable distances for mustering and for Inspection of bores etc. There would be, in these circumstances, conslderable advantage in establishing an out-station of the cattle profeot in this vestern areas the Acting Senior Stock Inspector In Alloe Springs of the Aninal Industry Branch, following a recent Inspection, has recoumended that we cons1der very strongly the establishment of an out-atation in this area. Th1s, together with the obvious advantages in relleving the population pressure at Papunya, seems to me to lend support to the view that it would be advisable to decentrallse activities from Papunga to this area. What the Director of Welfare has In mind so far as this area is concerned, is to have one of the Head Stockmen at present on this establlshment, stationed at one of the bores (Lelbig or one of thoce to the west. or southwest) to control the bores and cattle in this area under the Cattle Manager, and to move some 100 to 150 natives from Papunge to this area. This would be right in the Plntubl country and there would be no difficulty in having this group move to this area. In addit1on, at this profect the Director of Welfare suggests that there should be a Manager whose wife is a Nursing S1ster and, depending on the number of ahildren of pre-school and school age, one or two teaohers. If two teachers were recuired, a teaching couple would be appolnted to this location.

5. On this basis, the facilities reculred for such an out-atation would consist of -

(a) Three staff houses.

(b) Small nat1ve villago 1ncluding latrino/ ablut1on and laundry units.

(c) Small food store (60' $\times 24$ ' Nissen).

(d) Small kitchen/mess unlt (Inoluding cool room).

(e) Electricity supply.

(f) Rump, 5,000 gall. overhead tank and reticulation.

(g) Two elassrooms school unit (prefabricated Kingatrand).

(h) Garage, saddlery and equipaent store ( $961 \times 35$ ' Rorney).

6. The men could be employed on stook work (musterlng, fenoe and yard building, horse breaking etc.), at cutting and carting fence posts,

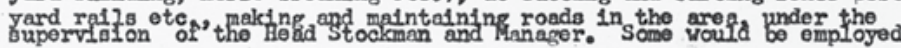


on hyglene, cooking and other duties in the homostead area. Buployment could also be found for the mnjority of the able-bodled women without young children in the area,

Equipment required for this profect would Inolude a landrover for the Head Stockmen, a 30 cwt. truck for general settlement duties (hyglene, servicing rosd gangs, fence gangs etc.) and $3 / 5$ ton truak for use of the gangs in carting fence posts, yard bullding etc. The out-atation would need, of course, to have a fixed transceiver for contaot with Papunya and Alice Springs; an alrstrip would of course be eseential and would be one of the first tasks undertaken by the natives in the aroa.

7. I vould 21ke to plan the dovelopsent of such an out-atation in the Mt. Leib1g area at this stage to relleve the populat1on, hyglene, and vater supply pressures at Papunga and at the seme time, onable the more effective control and managemont of the oattlo projeot in this area.

8.

Further developnent of out-stations in th1s area could be looked at then against the devolopwent of further waters in the western ares and on the basis of the development of this propoeod out-atation.

9. At Areyoriga where the water supply position quite obviously, is always going to present difficultios, I belleve we will have to cons1der two possible means of decentrelisation, one in the old Haasts Bluff Reserve area and the other in the Potormann Ranges area depending on the results which we obtain from the patrols and surveys which are at present being undertaken in this area.

10. Borling is at present going on at the Areyonga Settlement area and it is proposed then to move into the next valley near the alratrip and bore there. A further site has been seleoted at Amulds, some 5 miles along the road back to Al1ce Springs where there are extensive springs, and boring will take place at this location as soon as funds can be provlded for this purpose. It is proposed also, to look at the question of erecting a dam at Tent Hill whore there 1s already some permanent water. Planning is now proceeding to construot a road, to build: $a$ holding paddock and yards (Inoluding kdlling pen) at this site so that Instead of carting beef by open truck to Areyonga from Haasts Bluef, cattle will be moved on the hoof to Tent H1II, hold there and killed as required for Areyonga. It should bo possible, based on our present knowledge of the ares, to hold up to 150 head of cattle in this area. If the proposed dam to be erected in this area is successful and sufflelent water can be found, this appears one of the logical places frr an out-station at Areyonga, Again, it would be proposed to move from 100 to 150 of the natives from Areyonga and In this case, commenoe Ir'.tially with a Manager, Nurse and Schoolteacher, leaving developnent of a cattle out-station to the future.

Having regard to the fact that Adole Inksmala and at least one other of the part-coloured pastoralists from Hernannsburg, have run cattle in this area over meny years, it is reasonable to assume that the area south of the Marinds and east to the Gosses is suitable for oattle. In the future consideration could be given to appointing a Head Stockman, here again under the supervision of the Cattle Manager at Hassta Bluef. On this basis the run could be divided into three main areas with the Head Stockman from Hassts Bluff controlling tho country between the Bluff and the Marinis under the peneral supervision of the Cattle Manager. The appointment of this extra Head Stockman at th1s location would, in my view, enable a much more efflclent operation of a substantial plece of good cattle country and would provide a means of obtalning regular aupplies of beef in good condition for Areyonga Settlement.

11. If water were located in the aerodrome valley or at Amulda, the same development as is now in operation at Yuenduma vould be followed, 1.e. a small native villago would bo catablished with natives operating a smail market garden, eltrus orchard and lucerne plots. These would be close enough as at Yuenduru, to have the chlldren walk to school or be transferred by truck. 
So far as the Petermann Range area 1s concernod, I would propose to examtino the fleld reports frou the Patrol orficer and Sentor Research Offloer of the Welfare Branch, and from the techntas offlcers of the Antmal Induatry Branch and Water Resources Branch before placing any recomendation before the Mindster conoerning dovelopment in that area.

13. I have developed this proposal particularly at this stage so that the Minister may see what the thinking is here in overeoning some of the obvious problems which face us at these settlements in Central Austral1s. I bellev very strongly that somo such decentralisation programe as this is necossary to onable more effeotive control of tho population moving from west and south of this reserve, to provide a better neans for employment, to rellew population, hyglene and water supply pressures on the main settlement areas, and to provide better management and control of the cattle herd on the reservo.

14. Because of the mumbers at Papunya at the present time, the fact that we have bores in the Mt. Leiblg area with a good supply of potable water to maintain a population of this order, and the need for control and management of cattle in this area, I would propose to cormenoe the first of these out-atations in this aroa. At the same time, I would propose to contime with the development of the small village areas only at bores close to the sottlement at Yuendura and at Areyonga (when avatlable):

15. I whould be glad, therefore, if this proposel could be placed before the Ministor for his clearance in prinoiple and I will then, as
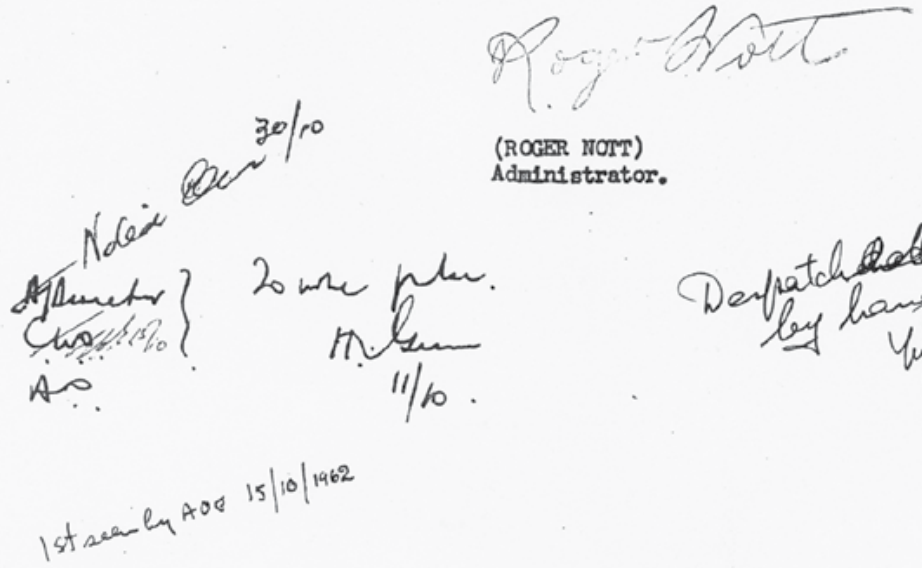

(ROGER MOTT)

Adninistrator.

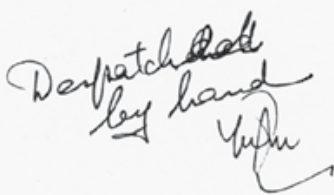


This text is taken from Experiments in self-determination: Histories of the outstation movement in Australia, edited by Nicolas Peterson and Fred Myers, published 2016 by ANU Press, The Australian National University, Canberra, Australia. 